Gournal of Science
http://dergipark.gov.tr/gujs

\title{
A Survey of the Morphology, Anatomy, and Palynology of Endemic Bornmuellera kiyakii and B. glabrescens (Brassicaceae) From Turkey
}

\author{
Burcu GONEN ${ }^{1}$ (1) , Huseyin DURAL ${ }^{1}$, Burcu YILMAZ CITAK ${ }^{1, *}$ \\ University of Selçuk, Faculty of Science, Department of Biology, 42130, Konya, Turkey
}

\author{
Highlights \\ - The anatomy of Bornmuellera genus are determined for the first time. \\ - Two types of leaf shape are defined: (1) linear, (2) triangular. \\ - Fruit and seed shape and colors are the most discriminative characteristics. \\ - In the species analyzed the pollen grains is similar.
}

Article Info

Received: $31 / 08 / 2018$ Accepted: 03/04/2019

\section{Keywords}

\section{Anatomy}

Brassicaceae

Bornmuellera

Fruit

Palynology

\begin{abstract}
In the present study, the morphological, anatomical, and palynological properties of 2 Bornmuellera Hausskn. taxa, which are endemic to Turkey, were examined. B. kiyakii Aytac \& Aksoy is known from the province of Konya, growing in serpentine areas, and B. glabrescens (Boiss. \& Balansa) Cullen \& T. R. Dudley is known from the province of Niğde. Through morphological analyses, the characteristics of the taxa were designated and the descriptions were expanded. The morphology of the stem, leaf, trichomes, and capsule are essential to separate the examined taxa. The anatomical analyses showed that the taxa had similar anatomical root, stem, and leaf tissue layers; however, their rows, and mesophyll thickness were different between the taxa. Anatomical traits, such as the presence of an endodermis in B. kiyakii, the pith region in the cross-sections of the stems, linear-shaped leaf in B. glabrescens, and triangular-shaped leaf in $B$. kiyakii have taxonomic importance. The pollen grains of the studied taxa were tricolpate, isopolar, and radial symmetrical, prolate-spheroidal, and had reticulate ornamentation. The fruit of $B$. kiyakii were characterized by globose, asymmetrical, and yellow-purplish-pink valves with rugose ornamentation, which clearly differed from that of B. glabrescens, which had ovoid, symmetrical, and light green-yellow valves. The seed traits clearly appeared to have taxonomic significance. The seeds of $B$. glabrescens were orbicular-shaped, yellowish-brown in colour, with reticulate ornamentation; however, the seeds of B. kiyakii were oblong-elliptic-shaped, and the tile was red-brown in colour.
\end{abstract}

\section{INTRODUCTION}

The family Brassicaceae, or mustard family, is a monophyletic group of about 338 genera and 3709 species with global distribution [1,2]. An evaluation of its morphology and generic circumscriptions, and a new tribal alignment was proposed by Al-Shehbaz [3]. According to this paper, 49 tribes were recognized. The genus Bornmuellera belongs to the tribe Alysseae $[3,4]$ and includes 7 species distributed from the southwestern Balkan Peninsula to Anatolia [5].

Haussknecht (1965) described the genus as having non-saccate deciduous sepals, white flowers with obtuse petals, filaments with appendages at the base, sessile subglobose glabrous fruit, and 2 seeds in each loculus [6]. Recent molecular phylogenetic analyses of the tribe Alysseae [7] revealed that the monotypic genera Leptoplax Schulz and Physocardamum Hedge phylogenetically nest within Bornmuellera, and thus should be included within it [8]. In a recent paper, the tribe Alysseae was revised according to its chromosome numbers and ploidy-level estimates, and the genus Bornmuellera was accepted as having 9 taxa [9], of 
which Bornmuellera angustifolia (Hausskn. ex Bornm.) Cullen \& T. R. Dudley, Bornmuellera baldaccii (Degen) Heywood, Bornmuellera davisii (Hedge) Rešetnik, Bornmuellera dieckii Degen, Bornmuellera emarginata (Boiss.) Rešetnik, and Bornmuellera tymphaea (Hausskn.) Hausskn. are endemics to the Balkans; and Bornmuellera cappadocica (Willdenow) Cullen \& T. R. Dudley, Bornmuellera glabrescens, and Bornmuellera kiyakii are endemics to Turkey.

In fact, a large data gap exists regarding anatomical and micromorphological studies for this species. Only morphological descriptions are presented in Flora of Turkey and East Aegean Islands [6,10]. Hence, the main goal of this study was to determine the detailed morphological, anatomical, palynological, and micromorphological properties of Bornmuellera kiyakii and B. glabrescens, which are morphologically very similar species, and provide useful data for the systematics of the genus.

\section{MATERIAL AND METHODS}

\subsection{Plant Sampling}

The field excursion for the studied taxa took place in the provinces of Konya (Bornmuellera kiyakii) and Niğde (B. glabrescens) in Turkey at different times (Table 1). Some of the collected materials were dried for morphological analysis, while others were stored in $70 \%$ ethanol for anatomical analysis. All of the specimens were deposited in the KNYA herbarium. Flora of Turkey and Aytaç \& Aksoy were followed for the herbarium specimens, which were examined using several morphological characters $[6,10]$. For the pollen grain observations, dried mature anthers were used from the herbarium materials.

Table 1. The localities of information for the studied taxa

\begin{tabular}{|l|l|l|}
\hline Taxa & Locality & Herbarium No. \\
\hline B. kiyakii & C3 Konya: Derebucak, Çamlık Village, Kızıldağ, 1400- & $\begin{array}{l}\text { H. Dural 3527-H. } \\
\text { Demirelma, B. Cltak }\end{array}$ \\
\hline B. glabrescens & C5 Niğde: Mazmıl1 Mountain, 25.06.2014, 1800-1850 m. & $\begin{array}{l}\text { H. Dural 3532-A. } \\
\text { Savran }\end{array}$ \\
\hline
\end{tabular}

\subsection{Morphological Measurements}

For each taxa, 15 specimens were studied for the morphological analyses and a minimum of 20 fruit and seed were used for the micromorphological analyses. All of the morphological characters were measured at least 10 times using either a ruler or Verner calliper. In light of these studies, the description of these species was expanded. Fruit and seeds were measured using a Vernier caliper and then photographed using a light microscope (LM) and later with Zeiss Evo LS10 scanning electron microscope (SEM). The Łangowski classification was used for the fruit and seed terminology [11]. Moreover, the trichomes of the examined taxa were directly investigated under a SEM. The classification systems of Ančev [12] and Goranova and Mutlu [13] were used for the trichome micromorphology terminology.

\subsection{Anatomical Techniques}

The paraffin method was used for the LM observations [14]. Sections of the roots, stems, and leaves were dehydrated in a graduated series of ethanol $(70 \%-100 \%)$ and then embedded in paraffin blocks, which were later cut into cross-sections of between 10-12 $\mu \mathrm{m}$ thick using a Thermo Scientific Shandon Finesse 325 rotary microtome. The cross-sections were stained using safranin-fast green and observed under a Leica DM 1000 LM. If the paraffin method was unsuccessful, the cross-sections were then cut by hand using a razor blade. The handmade cross-sections and superficial sections were stained with phloroglucinol-HCl. On average, 20 preparations were made for each type of section for the 20 pieces of plant material, and the cell groups were measured at least 30 times (Table 2). 


\subsection{Palynological Method}

The pollen grains were taken from the anthers and placed on glass slides, which were treated with $96 \%$ ethyl alcohol. Later, the glass slides were heated, and glycerin-gelatin with safranin was added, followed by mounting with Entellan [15]. Measurements and observations were made using a Leica DM 1000 LM attached to a Canon EOS 450D camera. A minimum of 30 pollen grains were measured using several palynological characters (Table 3). For the SEM observations, unacetolyzed pollen grains were first mounted on a double-sided carbon tape affixed to aluminium stubs, then covered with gold using a Cressington Auto 108 sputter coater, and photographed using a Zeiss Evo LS10 SEM. The pollen terminology of Punt et al. was followed [16].

\section{RESULTS}

\subsection{Morphological Characterization}

\section{Bornmuellera kiyakii}

Perennial herb, 7.5-15.3 cm, very branched from the base. Stems erect, 5.3-9.1 cm, sparsely hairy, hairs malpighiaceous (bifurcate). Leaves basal forming rosettes, filiform, 4-19 $\times 0.4-0.5 \mathrm{~mm}$, glabrescent to indumentum few malpighiaceous (bifurcate) or 3-4 branched hairs, stem leaves absent or few, similar to basal leaves but smaller. Inflorescens unbranched, corymbose, 12-20 flowered, elongating in fruit. Pedicel 2-7 mm in flowers, 4-11 mm in fruit, patent with sparse malpighiaceous (bifurcate) hairs. Sepals yellowish to greenish, elliptic, 2-3 $\times 2-3 \mathrm{~mm}$, with hyaline margins, with a few malpighiaceous (bifurcate) hairs. Petals white, orbicular, 3.5-4.5 $\times 2.5-3.5 \mathrm{~mm}$ attenuate into $1-2 \mathrm{~mm}$ claw, rounded at apex. Filaments linear, $1-2.5 \mathrm{~mm}$, with a small tooth at base, anthers $0.3 \times 0.6 \mathrm{~mm}$, white-cream; nectaries one on each side of the short stamens. Ovary globose, 1-2 $\times 1-2 \mathrm{~mm}$, glabrous; 4-ovulate ( 2 mature, 2 immature); style 0.5$0.7 \mathrm{~mm}$ in fruit; stigma capitate. Mature siliculae globose, inflated, $5.13 \times 3.45 \mathrm{~mm}$. Seeds ovoid, $2.49 \times$ $1.61 \mathrm{~mm}$. Flowering time May-June, 1400-1500 m., at the openings of Pinus nigra forest (Figure 1-a).

\section{Bornmuellera glabrescens}

Perennial herb, 23-36 cm. Stems erect, 13-27 cm, sparsely hairy, malpighiaceous (bifurcate) hairs. Leaves basal forming rosettes, oblanceolate, 7-21 $\times 0.5-1.5 \mathrm{~mm}$, malpighiaceous (bifurcate) hairs. Inflorescence unbranched, corymbose, 5-12 flowered, elongating in fruit. Pedicel 3-8 $\mathrm{mm}$ in flower, 5-9 $\mathrm{mm}$ in fruit, patent with sparse malpighiaceous (bifurcate) hairs. Sepals greenish, elliptic, 1-2 × 1.5-2 mm, with hyaline margins, with a few malpighiaceous (bifurcate) hairs. Petals white-cream, orbicular, 3-4 × 3.2-4 mm attenuate into 1-2 mm claw, rounded at apex. Filaments linear, 1-2 mm, with a small tooth at the base, anthers $0.24 \times 0.29 \mathrm{~mm}$, white-cream; nectaries one on each side of the short stamens. Ovary globose, $0.6-$ $1.5 \times 0.5-1.5 \mathrm{~mm}$, glabrous; 4-ovulate (2 mature, 2 immature); style $0.2-0.7 \mathrm{~mm}$ in fruit; stigma capitate. Mature siliculae ovoid, inflated, $6.59 \times 4.67 \mathrm{~mm}$. Seeds ovoid, $3.45 \times 3.12 \mathrm{~mm}$. Flowering time May-June, 1800-1850 m (Figure 1-b). 


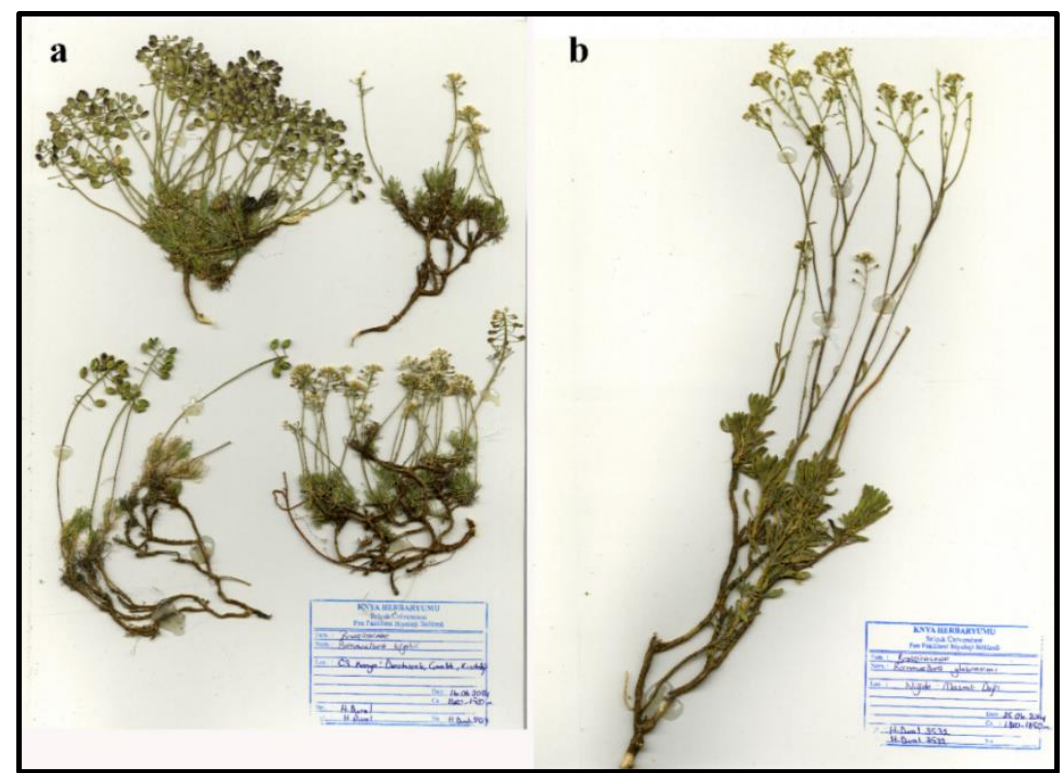

Figure 1. The general appearance of the studied Bornmuellera genus; (a) Bornmuellera kiyakii (b) B. glabrescens

\subsection{Anatomical Characterizations}

\section{Bornmuellera kiyakii}

Root: The outermost surface of the root had a peridermis as a protective tissue that was $50.46 \pm 4.29 \mu \mathrm{m}$ thick (Table 2). Phellem cells were arranged in 4 or 5 layers and rectangular in shape. However, the phellogen and phelloderm cells were not explicitly distinguished in the root cross-sections. The cortex parenchyma comprised 9-11 rows and was rectangular-oval in shape. The fibre caps were located between the cortex parenchyma cells and were agglomerate. They were pentagon-shaped and between 4-10 layers. The conducting tissue (xylem and phloem) was well developed and the cambium could not be distinguished clearly. The xylem tissue contained many more vessels and they were oval in shape. The centre of root was full of xylem (Figure 2-a).

Stem: The epidermis limited the cross-sections of the stems in their outermost surfaces. It was composed of a single layer that was oval-rectangular-shaped. Over the epidermis cells, there was a cuticle layer that was approximately $4 \mu \mathrm{m}$ thick (Table 2). Oval-shaped cortex parenchyma cells with abundant chloroplasts followed the epidermis, which was composed of 4-5 layers. A single row of endodermis cells (starch sheath) could be distinguished easily. Vascular bundles lined the inside of the phloem and outside of the xylem. The pith had a large cavity and the pith cells were characterized as parenchymatic (Figure 2-b).

Leaf: The cross-sections of the leaves were triangular in shape. Both surfaces had an epidermis, which was single-rowed, and covered by a cuticle (thickness; $5 \mu \mathrm{m}$ ). The mesomorphic stomata were on both sides of the leaves. The mesophyll tissue was composed of 2 types of cells, palisade and sponge parenchyma (equifacial type), and it was about $275 \mu \mathrm{m}$ thick (Table 2). Vascular bundles were collateral and the middle part was larger than the others (Figure 3-a). In the superficial sections, which were taken from the upper and lower surfaces of the leaves, the stomata were anisocytic (Figure 3-b,c). 

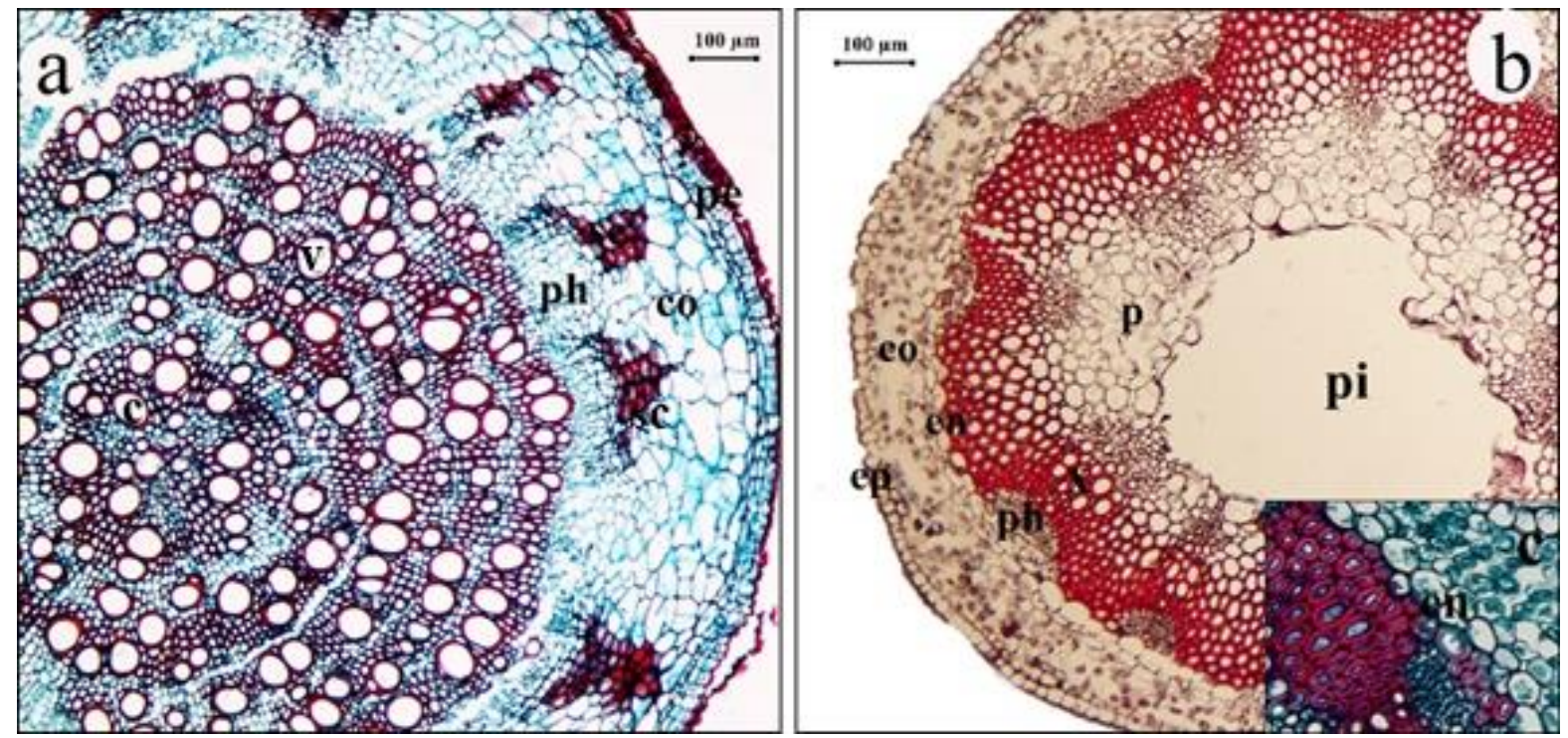

Figure 2. Bornmuellera kiyakii; a) Cross section of the root b) Cross section of the stem c) Endodermis. ep: epidermis, en: endodermis (starch sheath), p: parenchyma cell, pi: pith region pe: peridermis, co: cortex parenchyma, sc: sclerenchyma, ph: phloem, $x: x y l e m$, v: vessel, c: centre of the root

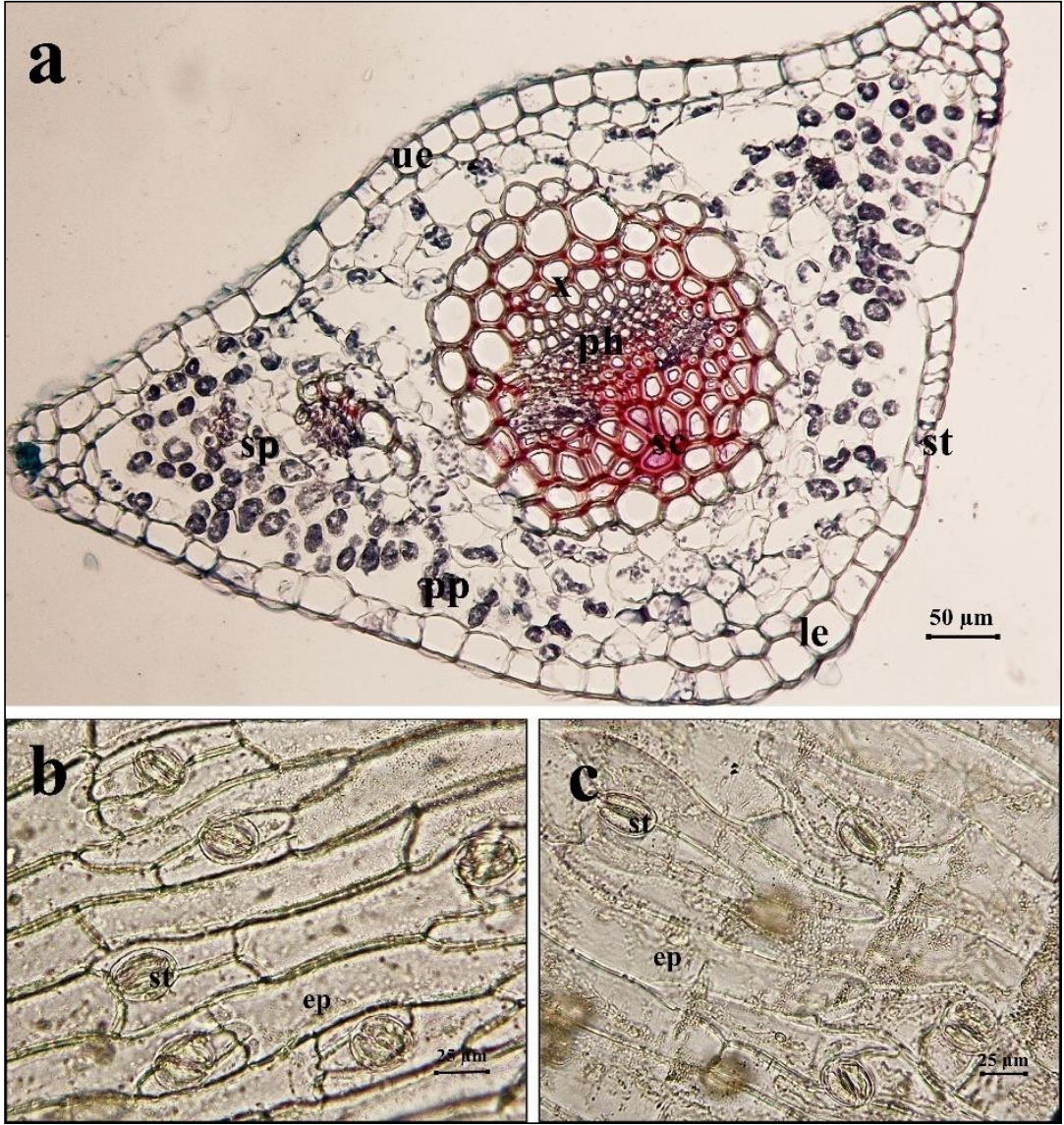

Figure 3. Bornmuellera kiyakii; a) Cross section of the leaf b) Superficial section of the upper surface of the leaf c) Superficial section of the lower surface of the leaf. ue: upper epidermis, le: lower epidermis, pp: palisade parenchyma, sp: spongy parenchyma, x: xylem, ph: phloem, sc: sclerenchyma, st: stomata, ep: epidermis

\section{Bornmuellera glabrescens}

Root: The cross-sections of the root had a secondary root structure. The peridermis was about $60 \mu \mathrm{m}$ and was surrounded by the roots (Table 2). The phellem was composed of 4 or 5 layers of rectangular-shaped 
cells. The phellogen and phelloderm cells were not clearly distinguished in the root cross-sections. The cortex parenchyma comprised 9-11 rows, and it was pentagonal-oval-shaped, and followed the peridermis towards the centre. Between the cortex cells, there were 3-11 layers of sclerenchymatic cells. The cambium could not be distinguished clearly and the phloem was fewer in number and size than the xylem. The xylem covered a large area around the centre of the root. The xylem contained many more vessels and they were oval in shape (Figure 4-a).

Stem: There were 4 anatomical parts; the epidermis, cortex, vascular bundles, and pith region. The epidermis was a single layer that was oval-rectangular in shape. The cortex was composed of 6-7 layers of parenchymatic cells. The phloem covered a small area and there were a few phloem fibres over it. The xylem covered a large area in the stem. The pith was composed of isodiametric parenchymatic cells (Figure 4-b).

Leaf: The cross-sections of the leaves were linear in shape. The epidermis was single-layered on both sizes of the leaf. There were 2 types of cells that could be distinguished in the mesophyll tissue, palisade parenchyma, and spongy parenchyma cells, and it was about $555 \mu \mathrm{m}$ thick (Table 2). The vascular bundle (collateral type), which was in the middle part of the leaves, was bigger than the others (Figure 5-a). In the Superficial sections, which were taken from the upper and lower surfaces of the leaves, the stomata were anisocytic and the leaves were amphistomatic (Figure 5-b,c).
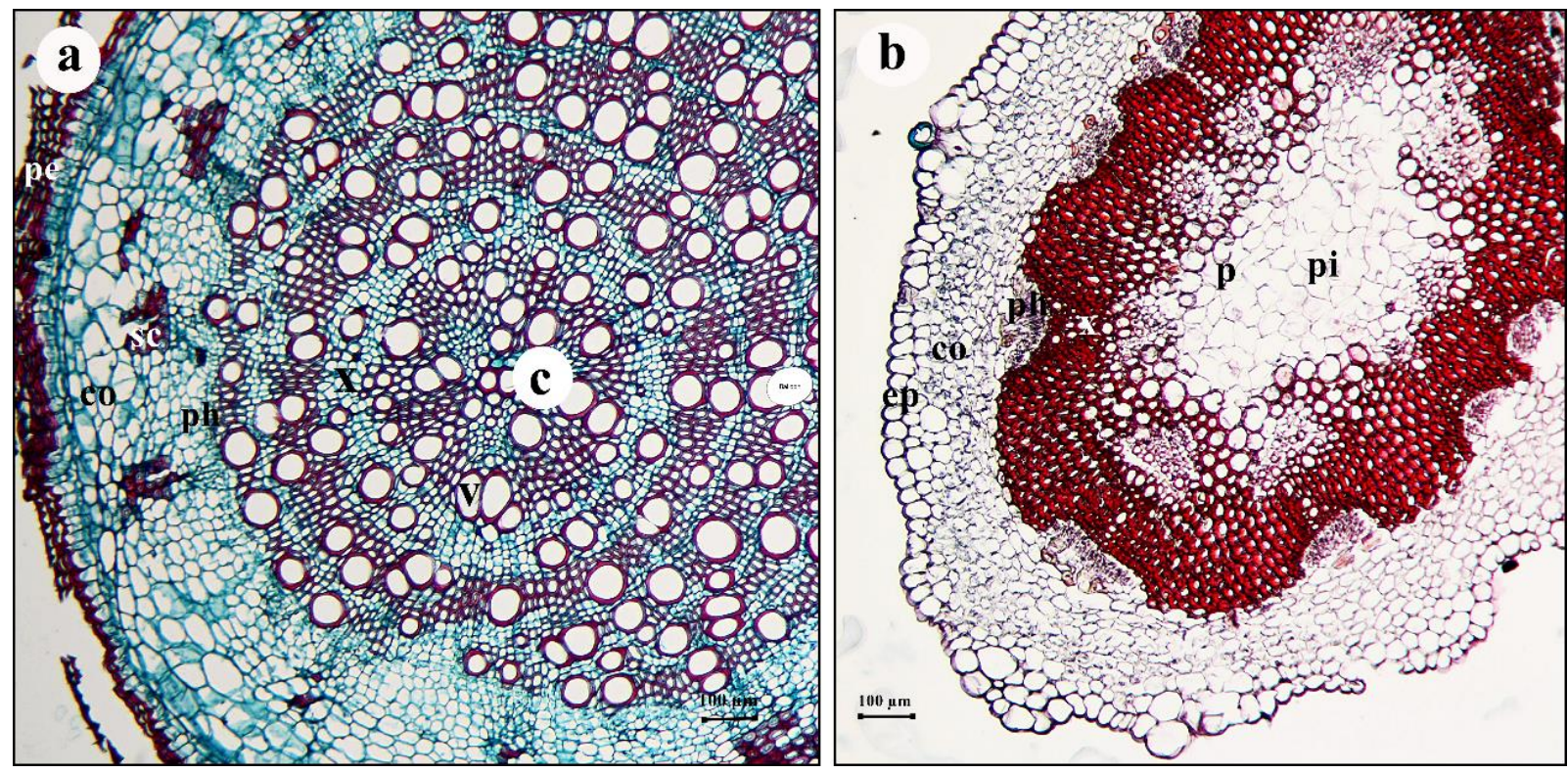

Figure 4. Bornmuellera glabrescens; a) Cross section of the root b) Cross section of the stem. pe: peridermis, co: cortex parenchyma, sc: sclerenchyma, ph: phloem, $x: x y l e m$, $v:$ vessel, $c:$ centre of the root, ep: epidermis, $p$ : parenchyma cell 


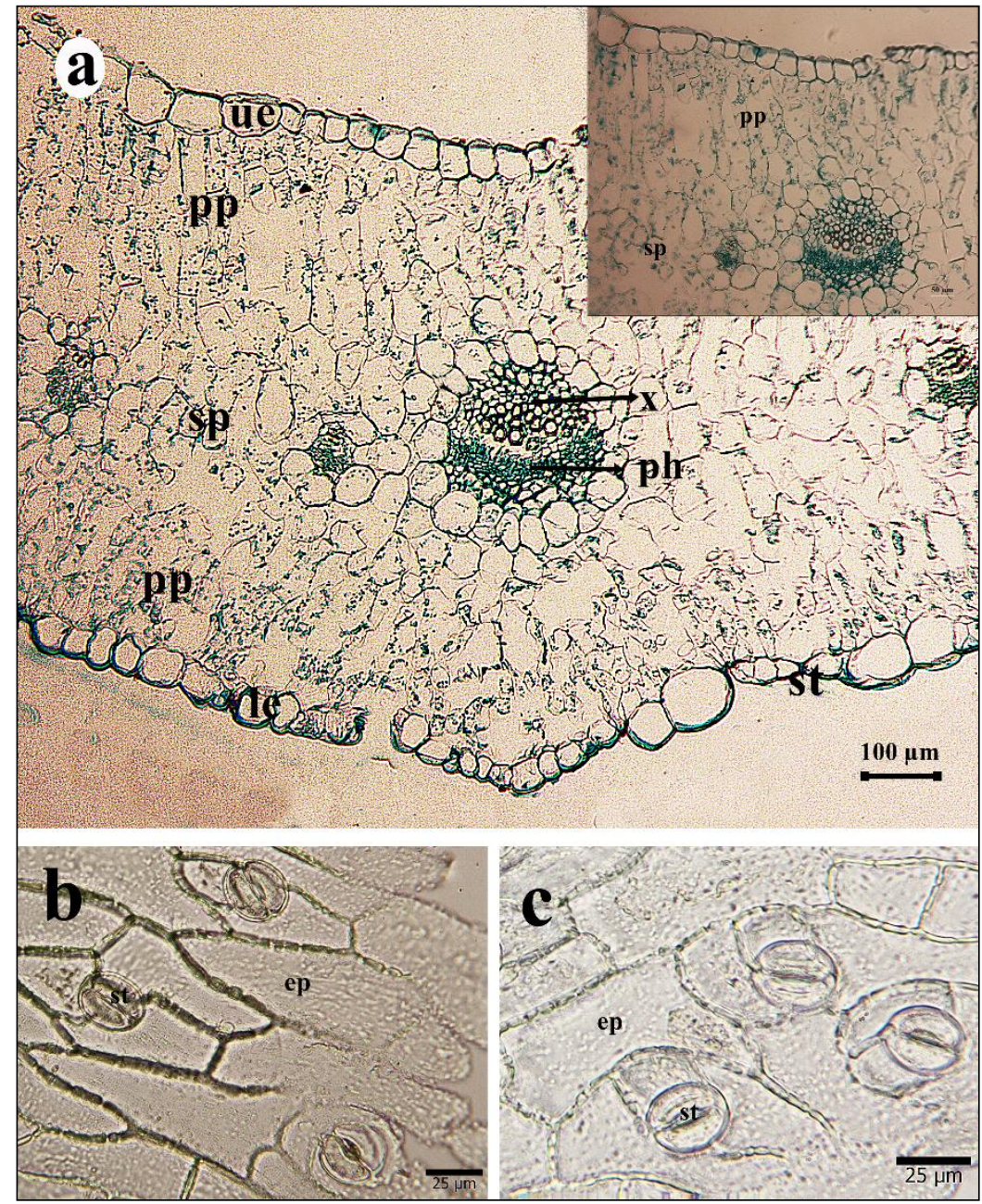

Figure 5. Bornmuellera glabrescens; a) Cross section of the leaf b) Superficial section of the upper surface of the leaf c) Superficial section of the of lower surface of the leaf. ue: upper epidermis, le: lower epidermis, pp: palisade parenchyma, sp: spongy parenchyma, x: xylem, ph: phloem, st: stomata, ep: epidermis

Table 2. Measurements of the anatomical characteristics of the studied taxa

\begin{tabular}{|c|c|c|c|c|c|c|c|c|}
\hline & \multicolumn{3}{|c|}{ Length $(\mu \mathrm{m})$} & \multicolumn{3}{|c|}{ Width $(\mu \mathrm{m})$} \\
\hline & & & Min & $\operatorname{Max}$ & Mean \pm SD & Min & Max & Mean \pm SD \\
\hline \multirow{12}{*}{ 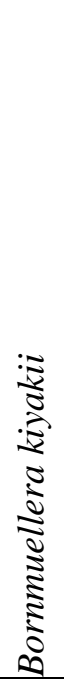 } & \multirow{4}{*}{ Root } & Peridermis & & & & 41.29 & 54.64 & $50.46 \pm 4.29$ \\
\hline & & Cortex cells & 11.33 & 23.41 & $18.38 \pm 2.82$ & 25.21 & 46.77 & $35.09 \pm 6.13$ \\
\hline & & Sclerenchyma & & & & 13.67 & 28.8 & $20.06 \pm 4.23$ \\
\hline & & Vessels & & & & 11.78 & 53.46 & $30.42 \pm 13.6$ \\
\hline & \multirow{4}{*}{ Stem } & Cuticle & & & & 2.45 & 5.99 & $3.96 \pm 0.81$ \\
\hline & & Epidermis & 11.78 & 17.34 & $14.11 \pm 1.89$ & 9.32 & 15.67 & $12.96 \pm 1.91$ \\
\hline & & Cortex cells & & & & 7.61 & 18.62 & $12.34 \pm 2.32$ \\
\hline & & Sclerenchyma & & & & 6.61 & 28.06 & $13.33 \pm 4.42$ \\
\hline & \multirow{4}{*}{ Leaf } & Upper cuticle & & & & 2.96 & 7.27 & $5.11 \pm 1.09$ \\
\hline & & $\begin{array}{l}\text { Upper } \\
\text { epidermis }\end{array}$ & 13.26 & 25.79 & $21.32 \pm 3.78$ & 12.11 & 30.79 & $22.88 \pm 5.95$ \\
\hline & & Mesophyll & & & & $\begin{array}{l}255.4 \\
5\end{array}$ & 303.39 & $274.64 \pm 19.5$ \\
\hline & & $\begin{array}{l}\text { Palisade } \\
\text { parenchyma }\end{array}$ & 16.58 & 39.97 & $28.87 \pm 6.03$ & 7.18 & 15.11 & $11.79 \pm 2$ \\
\hline
\end{tabular}

Min: minimum, Max: maximum, SD: Standard deviation 


\begin{tabular}{|c|c|c|c|c|c|c|c|c|}
\hline & & $\begin{array}{l}\text { Spongy } \\
\text { parenchyma }\end{array}$ & & & & 12.27 & 37.38 & $23.19 \pm 5.67$ \\
\hline & & $\begin{array}{l}\text { Lower } \\
\text { epidermis }\end{array}$ & 13.71 & 32.07 & $20.71 \pm 5.92$ & 15.3 & 36.37 & $22.71 \pm 6.46$ \\
\hline & & Lower cuticle & & & & 3.17 & 6.63 & $4.84 \pm 1$ \\
\hline \multirow{15}{*}{ 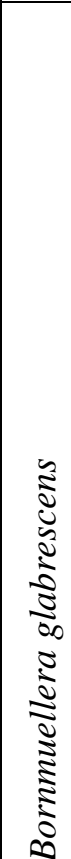 } & \multirow{4}{*}{ Root } & Peridermis & & & & 45.84 & 64.18 & $56.59 \pm 6.51$ \\
\hline & & Cortex cells & 9.58 & 35.85 & $22.49 \pm 7.5$ & 16.22 & 67.12 & $41.26 \pm 13.61$ \\
\hline & & Sclerenchyma & & & & 7.56 & 24.15 & $15.1 \pm 4.31$ \\
\hline & & Vessels & & & & 24.83 & 51.82 & $38.27 \pm 7.88$ \\
\hline & \multirow{4}{*}{ Stem } & Cuticle & & & & 4.25 & 7.68 & $5.78 \pm 0.86$ \\
\hline & & Epidermis & 20.8 & 40.38 & $26.53 \pm 5.14$ & 11.78 & 31.05 & $21.78 \pm 5.9$ \\
\hline & & Cortex cells & & & & 12.04 & 22.27 & $17.35 \pm 3.06$ \\
\hline & & Sclerenchyma & & & & 8.95 & 24.7 & $16.41 \pm 4.82$ \\
\hline & \multirow{7}{*}{ Leaf } & Upper cuticle & & & & 4.29 & 14.64 & $7.47 \pm 2.33$ \\
\hline & & $\begin{array}{l}\text { Upper } \\
\text { epidermis }\end{array}$ & 24.37 & 42.38 & $33.8 \pm 5.26$ & 17.4 & 71.42 & $40.57 \pm 13.59$ \\
\hline & & Mesophyll & & & & 515.7 & 600.16 & $554.64 \pm 36.6$ \\
\hline & & $\begin{array}{l}\text { Palisade } \\
\text { parenchyma }\end{array}$ & 32.59 & 91.43 & $56.91 \pm 12.6$ & 15.76 & 28.65 & $21.38 \pm 3.56$ \\
\hline & & $\begin{array}{l}\text { Spongy } \\
\text { parenchyma }\end{array}$ & & & & 25.03 & 56.39 & $38.98 \pm 8.93$ \\
\hline & & $\begin{array}{l}\text { Lower } \\
\text { epidermis }\end{array}$ & 15.44 & 45.92 & $30.37 \pm 7.13$ & 15.27 & 62.53 & $33.21 \pm 11.82$ \\
\hline & & Lower cuticle & & & & 3.17 & 5.79 & $4.54 \pm 0.78$ \\
\hline
\end{tabular}

\subsection{Palynological Characteristics}

Pollen grains of B. kiyakii were monad, isopolar, and tricolpate (Figures 6,7 ). The pollen grains were prolate-spheroidal in shape, the polar axis was $20.02( \pm 1.13) \mu \mathrm{m}$, and the equatorial axis was $19.7( \pm 0.77)$ $\mu \mathrm{m}, \mathrm{P} / \mathrm{E}$ 1.14. The pollen grains were triangular from a polar view and the Amb was $5( \pm 0.46) \mu \mathrm{m}$. The apocolpium was $10.41( \pm 1.71) \mu \mathrm{m}$. The colpi were long and narrow, Clg was $18.23( \pm 1.31) \mu \mathrm{m}$, Clt was $1.56( \pm 0.22) \mu \mathrm{m}$, and the distance between the 2 colpi was $7.63(0.07) \mu \mathrm{m}$. The exine was very thin, 1.28 $( \pm 0.11) \mu \mathrm{m}$ and intine was $0.62(0.04) \mu \mathrm{m}$. The exine ornamentation was identified as reticulate under LM and SEM (Figures 6-a,d and 7-b).

Pollen grains of $B$. glabrescens were monad, isopolar, and tricolpate. The pollen grains were prolatespheroidal in shape, the polar axis was $19.7( \pm 0.77) \mu \mathrm{m}$, and the equatorial axis was $18.48( \pm 1.17) \mu \mathrm{m}, \mathrm{P} / \mathrm{E}$ 1.06. The pollen grains were circular in polar view, and the Amb was $7.51( \pm 0.6) \mu \mathrm{m}$. The apocolpium was $13.03( \pm 2.18) \mu \mathrm{m}$. The colpi were long and narrow, Clg was $18.36( \pm 1.59) \mu \mathrm{m}$, Clt was $2.08( \pm 0.33) \mu \mathrm{m}$, and the distance between the 2 colpi was $10.52(0.67) \mu \mathrm{m}$. The exine was very thin, $1.64( \pm 0.33) \mu \mathrm{m}$ and intine was $0.92(0.13) \mu \mathrm{m}$. The exine ornamentation was identified as reticulate under LM and SEM (Figures 6-e,g,h and 7-d,c).

A summary of the pollen characters and measurements of the studied taxa is summarized in Table 3 . 

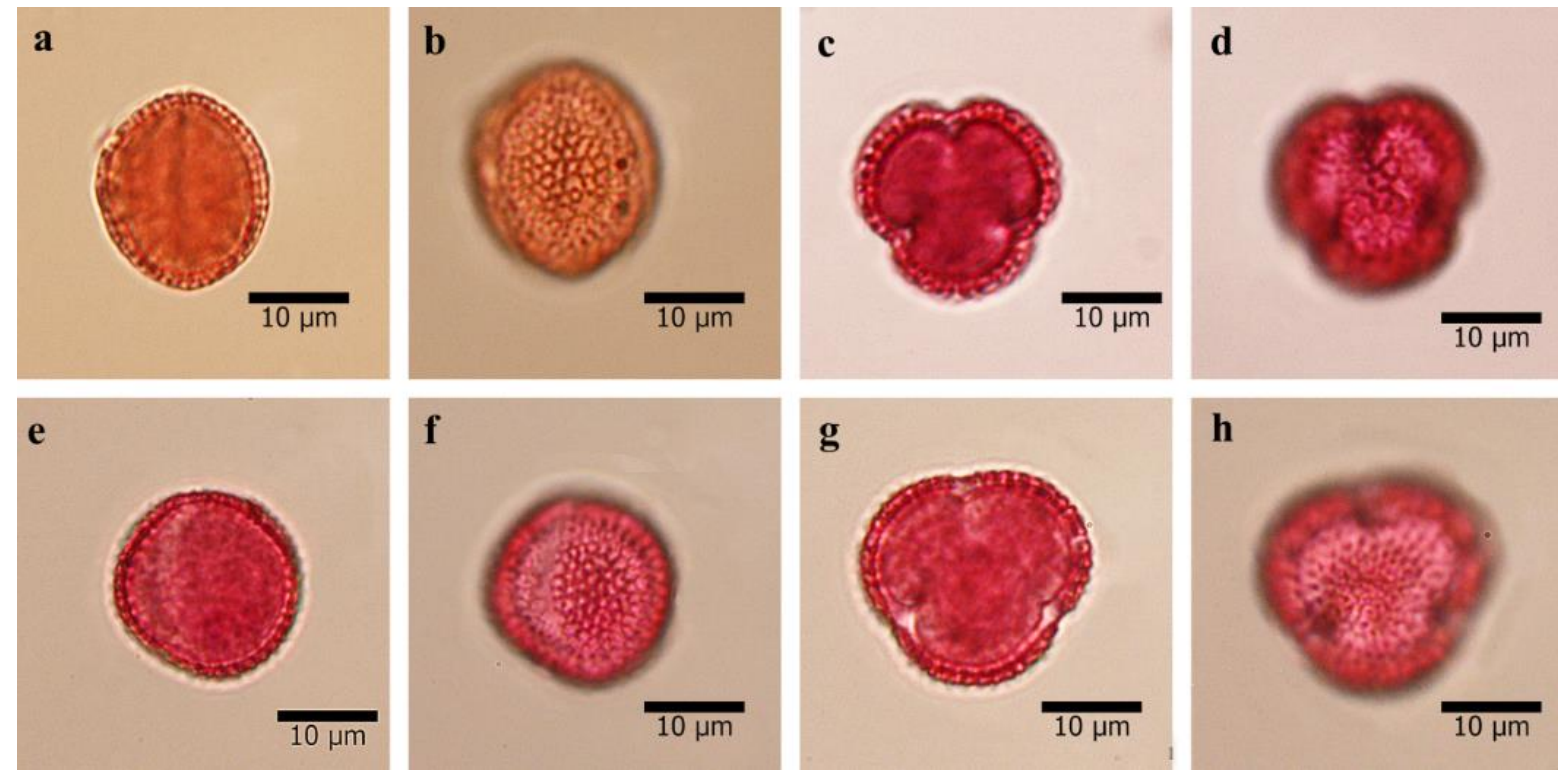

Figure 6. Pollen morphology of Bornmuellera kiyakii $(a-d)$ and B. glabrescens $(e-h)$ via LM
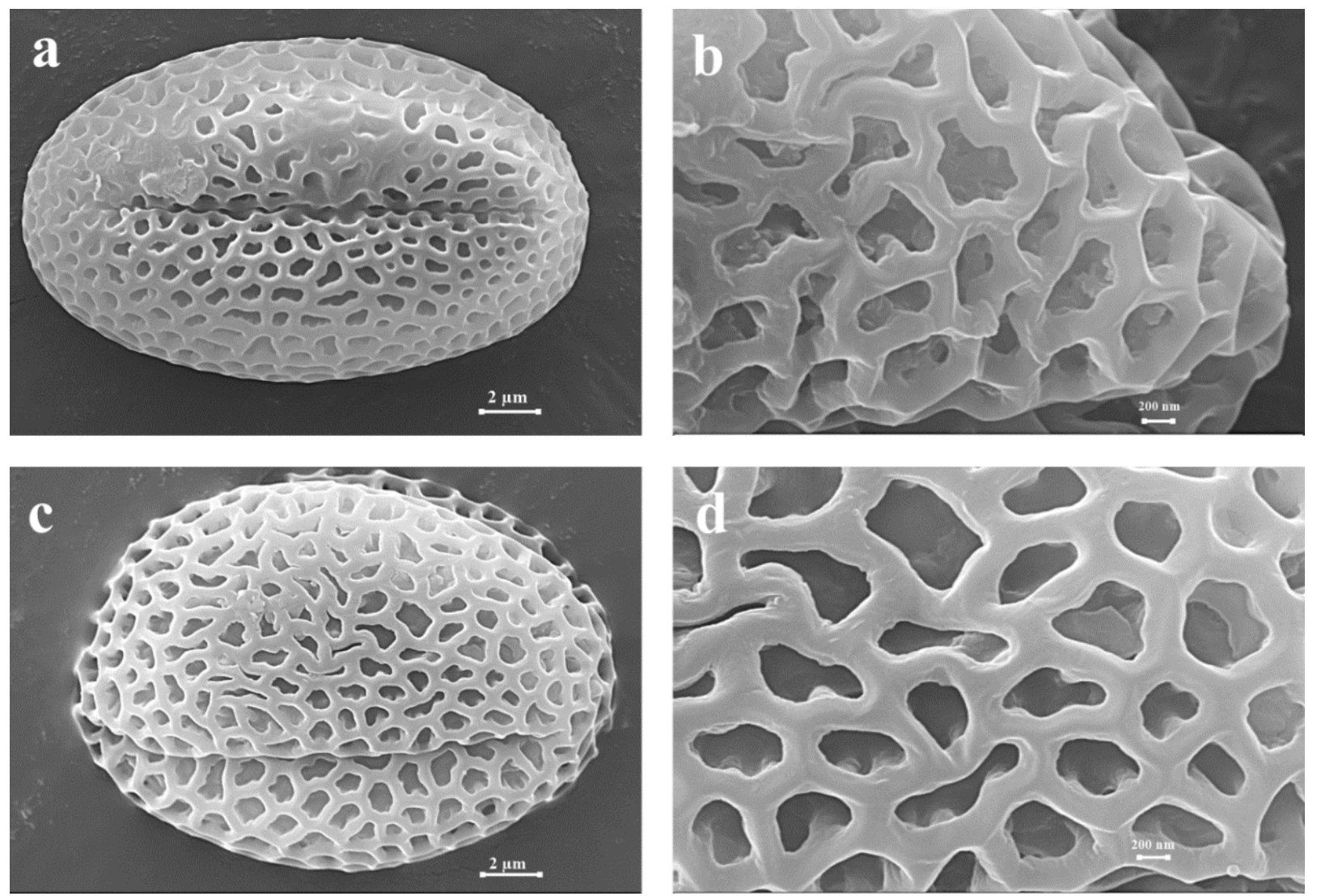

Figure 7. Pollen morphology of $a, b)$ Bornmuellera kiyakii and $c, d)$ B. glabrescens via SEM

Table 3. Pollen morphological data of B. kiyakii and B. glabrescens

\begin{tabular}{|l|l|l|}
\hline Pollen characteristics & B. kiyakii & B. glabrescens \\
\hline Equatorial axis $(\mathrm{E})$ & $19.7 \pm 0.77 \mu \mathrm{m}$ & $18.48 \pm 1.17 \mu \mathrm{m}$ \\
\hline Polar axis $(\mathrm{P})$ & $20.02 \pm 1.13 \mu \mathrm{m}$ & $19.7 \pm 0.77 \mu \mathrm{m}$ \\
\hline P/E & 1.14 & 1.06 \\
\hline Pollen shape & Prolate-spheroidal & Prolate-spheroidal \\
\hline Colpus length $(\mathrm{Clg})$ & $18.23 \pm 1.31 \mu \mathrm{m}$ & $18.36 \pm 1.59 \mu \mathrm{m}$ \\
\hline Colpus width $(\mathrm{Clt})$ & $1.56 \pm 0.22 \mu \mathrm{m}$ & $2.08 \pm 0.33 \mu \mathrm{m}$ \\
\hline
\end{tabular}




\begin{tabular}{|l|l|l|}
\hline Intercolpus distance & $7.63 \pm 0.07 \mu \mathrm{m}$ & $10.52 \pm 0.67 \mu \mathrm{m}$ \\
\hline Apocolpium & $10.41 \pm 1.71 \mu \mathrm{m}$ & $13.03 \pm 2.18 \mu \mathrm{m}$ \\
\hline Amb & $5 \pm 0.46 \mu \mathrm{m}$, triangular & $7.51 \pm 0.6 \mu \mathrm{m}$, circular \\
\hline Intine & $0.62 \pm 0.04 \mu \mathrm{m}$ & $0.92 \pm 0.13 \mu \mathrm{m}$ \\
\hline Exine & $1.28 \pm 0.11 \mu \mathrm{m}$ & $1.64 \pm 0.33 \mu \mathrm{m}$ \\
\hline Structure & Tectate & Tectate \\
\hline Sculpture & Reticulate. Muri are asymmetric, & $\begin{array}{l}\text { Reticulate. Muri are asymmetric, } 0.96 \pm \\
0.18 \mu \mathrm{m} \text { thick. }\end{array}$ \\
\hline
\end{tabular}

\subsection{Micromorphological Characteristics}

\section{Fruit features}

The fruit of B. kiyakii were globose, $3.43 \times 5.13 \mathrm{~mm}$, the fruit length/width ratio was 1.49 , and the apex and base of the fruit was round. There was no trichome over the fruit, but the style and replum were present, at $0.32 \pm 0.07 \mathrm{~mm}$. The septum was membranous. Valve was asymmetrical and transparent. The larger valve was yellow, while the smaller one was purplish-pink. The fruit had rugose ornamentation (Figure 8$a, b, c)$.

The fruit of B. glabrescens were ovoid, $4.67 \times 6.59 \mathrm{~mm}$, the fruit length/width ratio was 1.41 , and the apex and base of the fruit was round. There was no trichome over the fruit, but the style and replum were present, at $0.46 \pm 0.06 \mathrm{~mm}$. The septum was membranous. Valve was symmetrical, leather-like, and coarse. The valve was light greenish-yellow. The fruit had rugose ornamentation (Figure 8-d,e,f).
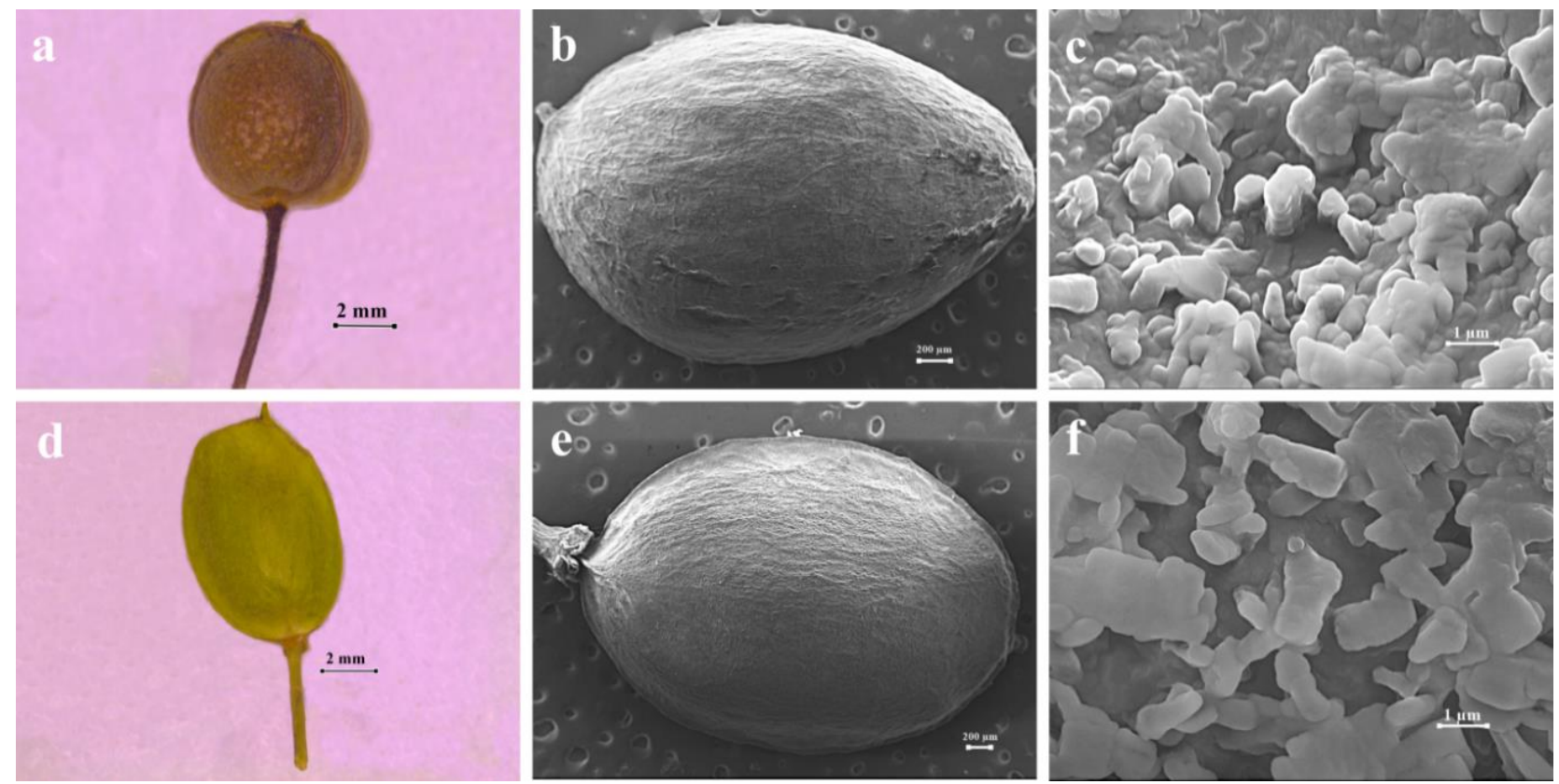

Figure 8. Fruit morphology of Bornmuellera kiyakii. $(a-c)$ and B. glabrescens $(d-f)$ via LM and SEM

\section{Seed Features}

The outline of the seeds of B. kiyakii was oblong-elliptic, $2.49 \times 1.61 \mathrm{~mm}$, and the length/width ratio was 1.54. The dorsal face was concave in shape, hilum was distinct, chalazal and micropylar poles were rotundate, tile was reddish-brown, and it weighed $0.0005 \mathrm{~g}$. The seed had reticulate-rugose ornamentation and the wing had rugose-striate ornamentation. The wing was $0.13 \pm 0.03 \mathrm{~mm}$, muri were $25.28 \pm 6.96 \mu \mathrm{m}$, and the walls of the muri were sinuous (Figure 9-a,b,c).

For B. glabrescens, it was orbicular, $3.45 \times 3.12 \mathrm{~mm}$, and the length/width ratio was 1.1 . The shape of dorsal face was concave, hilum was not distinct, chalazal and micropylar poles were rotundate, colour was 
yellowish-brown, and it weighted $0.0036 \mathrm{~g}$. The seed and wing both had reticulate ornamentation. The wing was $0.26 \pm 0.13 \mathrm{~mm}$, muri were $23.56 \pm 6.41 \mu \mathrm{m}$, and the walls of the muri were ruined (Figure 9-d,e,f).
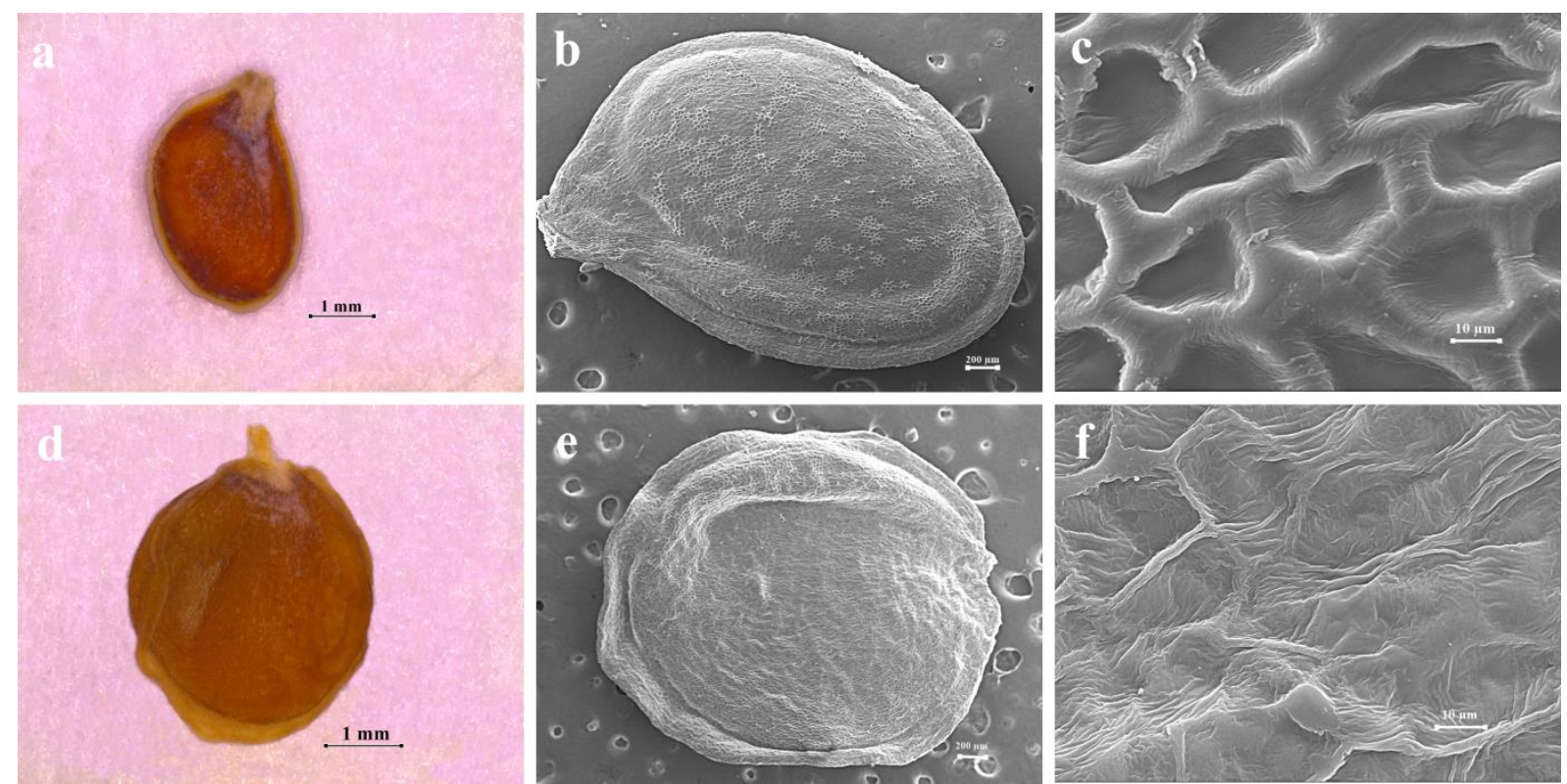

Figure 9. Seed morphology of Bornmuellera kiyakii. $(a-c)$ and B. glabrescens $(d-f)$ via LM and SEM

\subsection{Trichome Features}

Both B. kiyakii and B. glabrescens had malpighiaceous trichomes that were 2-rayed, which are characterized in the family Brassicaceae (Figures 10-a and 11-a,b). However, B. kiyakii also contained 3rayed and 4-rayed trichomes (Figure 10-b,c).
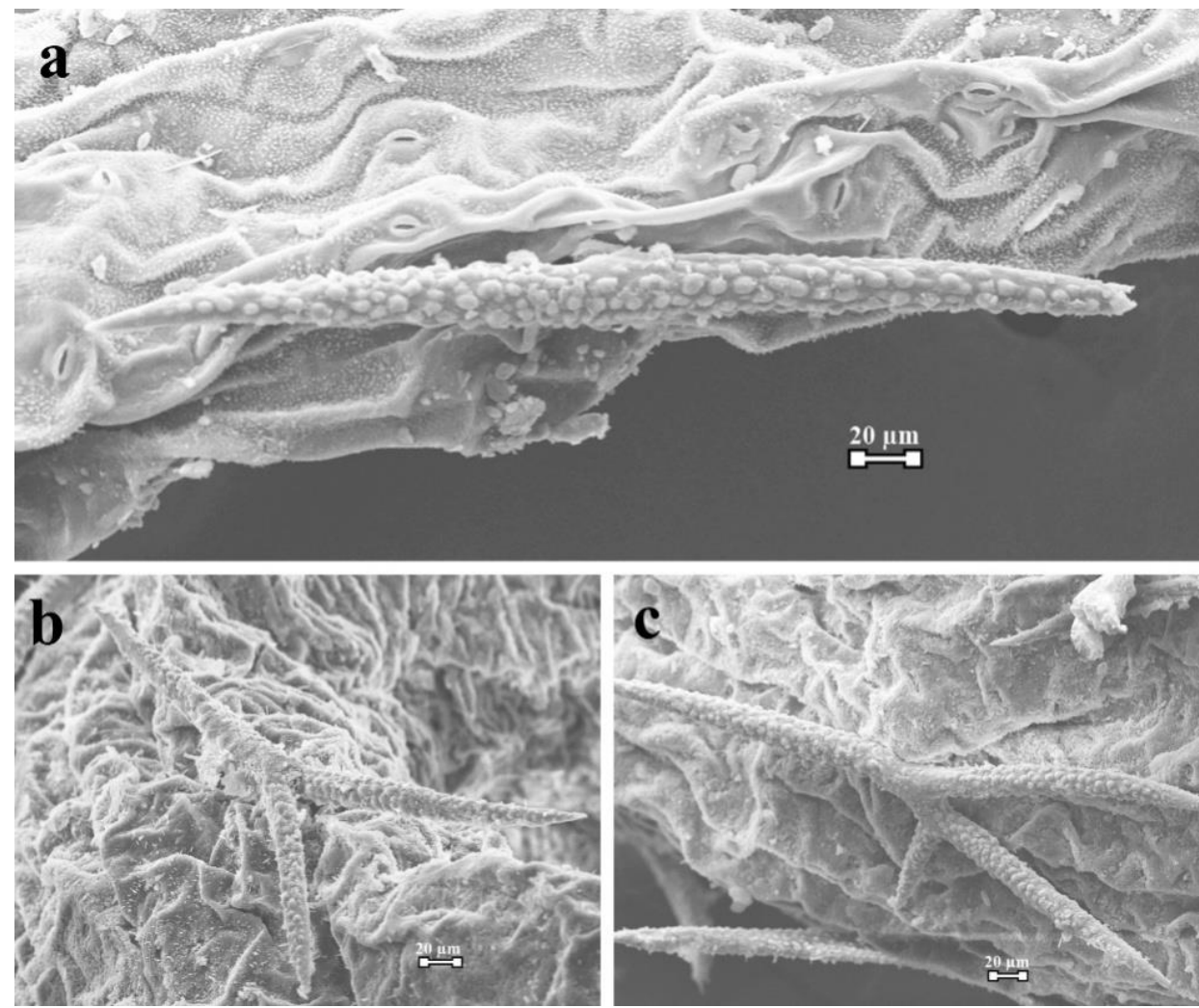

Figure 10. Bornmuellera kiyakii trichome morphology (SEM); a) Malpighiaceous trichome b) 3-rayed c) 4-rayed 

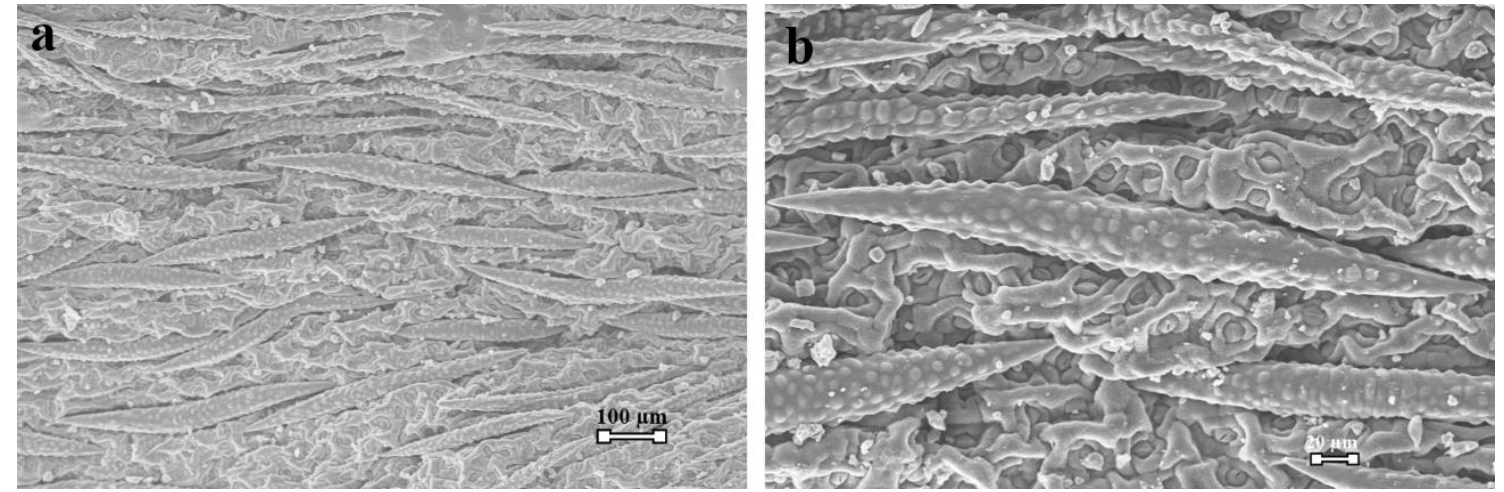

Figure 11. Bornmuellera glabrescens malpighiaceous trichomes (SEM)

\section{Key for Distinguishing the Examined Taxa}

1. Basal leaves filiform, petals whitish-cream, mature fruit globose, seeds $2.49 \times 1.61 \mathrm{~mm}$, trichomes 2-, 3, and 4-rayed.....

\section{B. kiyakii}

2. Basal leaves oblanceolate, petals white, mature fruit ovoid, seeds $3.45 \times 3.12 \mathrm{~mm}$, trichomes only 2 rayed.

B. glabrescens

\section{DISCUSSION}

Our morphological observations and measurements of Bornmuellera kiyakii and B. glabrescens were mostly congruent with previous studies $[6,10]$. Specifically, the morphological description of $B$. glabrescens was expanded with the present study.

No literature exists regarding the anatomical structure of the genus Bornmuellera and our study is the first report for the anatomy of Bornmuellera kiyakii and B. glabrescens, which are very distinctive endemic plants for Anatolia. In the root cross-sections, B. kiyakii and B. glabrescens had a similar secondary structure with regards to their peridermis, cortex parenchyma, xylem, phloem, and pith region, as was reported in the root anatomy of the family Brassicaceae (Cruciferae) [17-19]. Most species have a single cambium; growth rings are inconspicuous, with narrow vessels ranging from 16-71 $\mu \mathrm{m}$ in the wood anatomy of Brassicaceae (Carlquist 1971), as with B. kiyakii and B. glabrescens [20]. The studied taxa shared similar stem anatomical characteristics, which were characterized by a single-layered epidermis, containing chloroplasts in the cortex parenchyma, well-developed phloem, and xylem and pith cells in the centre. The leaves of B. kiyakii were triangular in shape and the median vascular bundle was larger than the others. However, B. glabrescens had linear-shaped leaves and the median vascular bundle was larger, as with B. kiyakii. The mesophyll was about 2 times greater in B. glabrescens than in B. kiyakii (Table 2). The other anatomical measurements are given in Table 2 and they are similar in the studied taxa. Small rhombic crystals were present in the libriform fibres of the Parolinia ornata Webb and Descurainia briquetii Webb in Brassicaceae [20-22].

When considering the genera in the tribe Alysseae, the fruit characteristics are important diagnostic macromorphological aspects that can help in distinguishing genus or taxa [9]. |The genus Bornmuellera has fruit with no trichomes, terete, dehiscent, and thin leathery silicules [8] and there have been no investigations regarding the fruit micromorphology of the genus. In this study, the fruit micromorphology of $B$. kiyakii and $B$. glabrescens are presented for the first time. In B. kiyakii, the fruit were globose, valves were asymmetrical, transparent, and the larger valve was yellow, while the smaller one was purplish-pink. In spite of this, in B. glabrescens the fruit were ovoid, valves were symmetrical, leather-like, and the valve in the fruit was light greenish-yellow. Both of the studied taxa had similar fruit ornamentation (rugose). The investigation of the fruit of the genus Bornmuellera will be a guide for future discussions.

Pollen and seed morphology can contribute useful taxonomic characters for the identification and classification of Brassicaceae species [13, 23-29]. Palynological investigations about the family Brassicaceae were performed by Erdtman, who reported that Brassicaceae was a stenopalynous family with 
pollen grains 3-zonocolpate, generally prolate to subprolate oblate to oblate-spheroidal, or prolatespheroidal and reticulate or granulate exine ornamentation [23]. The same researcher reported reticulate and granulate pollen types, on the basis of the exine thickness of 2 pollen types that were identified by Erdtman in Brassicaceae [24]. Abdel Khalik et al. divided the family into 3 pollen types on the basis of the lumina size [30]. Perveen et al. recognized 4 distinct pollen types on the basis of the tectal surface (Arabis bijuga, Erysimum melicentae, Farsetia ramosissima, and Draba lanceolate) [26]. When we looked at our palynological results for B. kiyakii and B. glabrescens, their pollen was reticulate according to the study of Erdtman, type I (exine microreticulate) according to Abdel Khalik et al., and Arabis bijuga according to Perveen et al. [26, 30]. On the other hand, in a recent study of the genus Bornmuellera, Firat \& Baser reported that Bornmuellera cappadocica had pollen grains that were prolate-spheroidal, 15.37-21.55 $\mu \mathrm{m}$ in the polar axis, and 14.48-20.29 $\mu \mathrm{m}$ in the equatorial axis [31]. The investigated species were only different with regards to the shape of the Amb, which was triangular in B. kiyakii and circular in B. glabrescens. The distance between the 2 colpi was also longer in B. glabrescens than in B. kiyakii (Table $3)$.

Regarding the seed morphology, our observations and measurements showed that B. kiyakii had a larger seed size than B. glabrescens, and the seed of B. kiyakii was oblong-elliptic in shape, while that of $B$. glabrescens was orbicular. In addition, Firat and Baser reported that B. cappadocica had seeds that were $1.82 \times 2.72 \mathrm{~mm}$, yellow, ovate in shape, and rugulose-striate ornamentation [31]. The seed colour was different in the 2 studied taxa than those of B. cappadocica. We concluded that the seed colour, shape, and size are diagnostic characters for distinguishing the members of the genus Bornmuellera.

Trichome morphology was used by many authors as an important character in the classification of Brassicaceae [12, 32-39]. In a recent paper, malpighiaceous trichomes, which were determined as '2-rayed and medifixed' were found in the genus Bornmuellera [9]. Both B. kiyakii and B. glabrescens had malpighiaceous trichomes over their leaves and stems (Figures 10-a, 11-a,b). Additionally, B. kiyakii also had 3-4-rayed trichomes, especially in its leaves (Figure 10-b,c).

As a conclusion, there have been no detailed studies on the Turkish local endemics B. kiyakii and B. glabrescens prior to this research. Our study is accordingly, the first comprehensive research of the morphology, pollen, anatomy, fruit, and seeds of both taxa. The results showed that the studied taxa were generally similar to each other in pollen morphology. However, the anatomical characters and morphological characters of the fruit, and the seed micromorphology of the samples, indicated some differences.

\section{ACKNOWLEDGMENTS}

We would like to thank Dr. Ahmet Savran and Dr. Hakk1 Demirelma for their assistance with the field excursion, Dr. Hasan Hüseyin Doğan for his light microscope investigation of the fruit and seeds, and the Selçuk University Scientific Research Unit for their financial support (Project number is 15201002).

\section{CONFLICTS OF INTEREST}

No conflict of interest was declared by the authors.

\section{REFERENCES}

[1] Hall, J.C., Sytsma, K.J. and Iltis, H.H., "Phylogeny Of Capparaceae And Brassicaceae Based On Chloroplast Sequence Data", American Journal of Botany, 89(11): 1826-1842, (2002).

[2] Bailey, C.D., Koch, M.A., Mayer, M., Mummenhoff, K., O’Kane Jr, S.L., Warwick, S.I., Windham, M.D. and Al-Shehbaz, I.A., "Toward a Global Phylogeny of the Brassicaceae", Molecular Biology and Evolution, 23(11): 2142-2160, (2006).

[3] Al-Shehbaz, I.A., "A generic and tribal synopsis of the Brassicaceae (Cruciferae)" Taxon 61(5): 931954, (2012). 
[4] Al-Shehbaz, I.A., Beilstein, M.A. and Kellogg, E.A., "Systematics and phylogeny of the Brassicaceae (Cruciferae): an overview", Plant Systematics and Evolution, 259(2-4): 89-120, (2006).

[5] Warwick, S.I., Francis, A. and Al-Shehbaz, I.A., "Brassicaceae. Species checklist and database on CD-Rom", Plant Systematics and Evolution, 259(2-4): 249-258, (2006).

[6] Cullen, J. "Bornmuellera", In: Davis, P.H. (Ed.) "Flora of Turkey and the East Aegean Islands". Edinburg University Press, Edinburg, (1965).

[7] Rešetnik, I., Satovic, Z., Schneeweiss, G.M. and Liber, Z., "Phylogenetic relationships in Brassicaceae tribe Alysseae inferred from nuclear ribosomal and chloroplast DNA sequence data" Molecular Phylogenetics and Evolution, 69(3): 772-786, (2013).

[8] Rešetnik, I., Schneeweiss, G.M. and Liber, Z., "Two new combinations in the genus Bornmuellera (Brassicaceae)", Phytotaxa, 159(4): 298-300, (2014).

[9] Španiel, S., Kempa, M., Salmerón-Sánchez, E., Fuertes-Aguilar, J., Mota, J.F., Al-Shehbaz, I.A., German, D.A., Olšavská, K., Šingliarova, B., Zozomová-Lihova, J. and Marhold, K., "AlyBase. database of names, chromosome numbers, and ploidy levels of Alysseae (Brassicaceae), with a new generic concept of the tribe", Plant Systematics and Evolution, 301(10): 2463-2491, (2015).

[10] Aytac, Z. and Aksoy, A., "A new species of Bornmuellera Hausskn. (Brassicaceae) from south Anatolia, Turkey" Botanical Journal of the Linnean Society, 134(3): 485-490, (2000).

[11] Łangowski, Ł., Stacey, N. and Østergaard L., "Diversification of fruit shape in the Brassicaceae family", Plant Reproduction, 29(1-2):149-163, (2016).

[12] Ančev, M. and Goranova, V., "Trichome morphology of eleven genera of the tribe Alysseae (Brassicaceae) occurring in Bulgaria", Willdenowia, 36(1): 193-204, (2006).

[13] Mutlu, B. and Erik, S., "Pollen morphology and its taxonomic significance of the genus Arabis (Brassicaceae) in Turkey", Plant Systematics and Evolution, 298(10): 1931-1946, (2012).

[14] Johansen, D.A., Plant Microtechnique. McGraw-Hill Book Co., New York, (1940).

[15] Wodehouse, P.P., Pollen Grains, McGraw-Hill, New York, (1935).

[16] Punt, W., Hoen, P.P., Blackmore, S., Nilsson, S. and Le Thomas, A., "Glossary of pollen and spore terminology", Review of Palaeobotany and Palynology, 143(1-2): 1-81, (2007).

[17] Pinar, N.M., Duran, A., Ceter, T., and Tug, G.N., "Pollen and seed morphology of the Genus Hesperis L. (Brassicaceae) in Turkey", Turkish Journal of Botany, 33(2): 83-96 (2009).

[18] Tekin, M., Yilmaz, G. and Martin, E., "Morphological, Anatomical and Palynological Studies on Endemic Matthiola anchoniifolia Hub.-Mor. (Brassicaceae)", Notulae Scientia Biologicae, 5(2): 163$168,(2013)$.

[19] Atceken, M.M., Dural, H. and Citak, B.Y., "The morphological, anatomical and palynological investigations on some taxa of genus Aethionema A. T. Waiton (Brassicaceae)" Biological Diversity and Conservation, 9(1): 55-68, (2016).

[20] Carlquist, S. "Wood anatomy of Macaronesian and other Brassicaceae" Aliso, 7(3): 365-384, (1971).

[21] Schweingruber, F.H., "Anatomical characteristics and ecological trends in the xylem and phloem of Brassicaceae and Resedaceae". IAWA Journal, 27(4): 419-442, (2006). 
[22] Carlquist, S. "Wood Anatomy of Brassicales. New information, new evolutionary concepts", The Botanical Review, 82(1): 24-90, (2016).

[23] Erdtman, G., Pollen Morphology and Plant Taxonomy. Angiosperms, Chronica Botanica Co.,Waltham, Massachusettes, (1952).

[24] Erdtman, G., Praglowski, J. and Nilsson, S., An Introduction to a Scandinavian Pollen Flora. II Almqvist \& Wicksell, Stockholm, (1963).

[25] Abdel Khalik, K. and Van Der Maesen, L.J.G., "Seed morphology of some tribes of Brassicaceae implications for taxonomy and species identification for the flora of Egypt", Blumea, 47(2): 363-383, (2002).

[26] Perveen, A., Qaiser, M. and Khan, R., "Pollen Flora of Pakistan -XLII. Brassicaceae", Pakistan Journal of Botany, 36: 683-700, (2004).

[27] Ghaempanah, S., Ejtehadi, H., Vaezi, J. and Farsi, M., "Seed-coat anatomy and microsculpturing of the genus Erysimum (Brassicaceae) in Northeast of Iran", Phytotaxa, 150(1): 41-53, (2013).

[28] Ozudogru, B., Akaydın, G., Erik, S. and Mummenhoff, K., "Seed morphology of Ricotia (Brassicaceae) and its phylogenetic and systematic implication", Flora, 222: 60-67, (2016).

[29] Sagun, V.G. and Auer, C., "Pollen morphology of selected Camelineae (Brassicaceae)", Palynology, 41(2): 255-266, (2017).

[30] Abdel Khalik, K., Van Den Berg, R.G. Van Der Maesen, L.J.G. and El Hadidi, M.N., "Pollen morphology of some tribes of Brassicaceae from Egypt and its systematic implications", Feddes Repertorium, 113(3-4): 211-223, (2002).

[31] Firat, M. and Baser, B. "Pollen and seed morphology of species Physocardamum davisii and Bornmuellera cappadocica", Biological Diversity and Conservation, 8(3): 168-172, (2015).

[32] Hayek, A., "Cruciferae. In Prodromus Florae Peninsulae Balcanicae 1", Repertorium Specierum Novarum Regni Vegetabilis, 30: 370-485, (1925).

[33] Janchen, J., "Das System der Cruciferen”, Oesterreichische botanische Zeitschrift, 91: 1-28, (1942).

[34] Nyárády, B.I., Alyssum L., In: Savulescu, T. (Ed.) Flora Republicii Populare Romîne, Bucureîti, (1955).

[35] Dudley, T.R., "Synopsis of the genus Alyssum", Journal of Arnold Arboretum, 45(3): 358-373, (1964).

[36] Greuter, W., "Note sur deux variétés grecques d'Alyssum doerfleri (Cruciferae) et sur la classification de quelques espèces vivaces de ce genre", Candollea, 29: 135-146, (1974).

[37] Rollins, R.C. and Banerjee, U.C., Trichomes in studies of the Cruciferae. In: Vaughan, J.G., MacLeod, A.J. and Jones B.M.J. (Eds.) The biology and chemistry of the Cruciferae, Academic Press, London, (1979).

[38] Al-Shehbaz, I.A., "The genera of Alysseae (Cruciferae; Brassicaceae) in the Southeastern United States" Journal of the Arnold Arboretum, 68(2): 185-240, (1987).

[39] Mutlu, B., "New morphological characters for some Erysimum (Brassicaceae) species", Turkish Journal of Botany, 34(2): 115-121, (2010). 